\title{
A UK study: vocational experiences of young adults with juvenile idiopathic arthritis
}

\author{
Laura E. Lunt ${ }^{1,2}$, Ailsa Bosworth ${ }^{3}$, Matthew Bezzant ${ }^{3}$, Karen Walker-Bone ${ }^{4}$, Kimme L. Hyrich ${ }^{1,2}$, Wendy Thomson ${ }^{2,5}$, \\ Janet E. McDonagh ${ }^{1,2}$ and Suzanne M. M. Verstappen ${ }^{1,2,4^{*}}$
}

Keywords: Transitional care, Vocational development, Young people, Rheumatic and musculoskeletal diseases

\section{Main text}

We commend Dr. Walter and colleagues [1] for their evaluation of a clinical transition pathway for young people with rheumatic and musculoskeletal diseases. Their work highlights a successful health transition model and as indicated in their findings, addresses some of the EULAR/PReS transitional care recommendations [2]. However we were interested to read the significant proportions of young people reporting a negative impact of their condition on education/vocational aspects of their lives [1]. By definition, transitional care should address vocational as well as medical, social and psychological issues as young people move into adult services.

We would like to draw your attention to our recent UK survey of $16+$ year olds on this topic which included 19 young adults, ( $n=17$ female $n=17$ white British) diagnosed with juvenile idiopathic arthritis [3]. Young people participating in a national survey, when in education, reported a lack of careers guidance. 8/14 respondents felt their school careers adviser did not take their condition into account when providing careers information/advice. Respondents reported the lack of support in schools for students with additional needs in planning their work experience; for example, 10/14 respondents reported a lack of information on possible limitations they may encounter on a work experience placement/ traineeship (Table 1).

Young people do take their condition into consideration when planning a career. 8/14 respondents changed their career path because of their condition reflecting the results reported by Walter et al. [1] Reasons for this included the need to stay healthy, physical demands or to manage symptoms. It is unclear in our study if these changes were seen as positive or negative. However, as highlighted by Walter et al., some young people with rheumatic diseases perceive their condition to have a negative effect on their chosen vocation/career [1].

The EULAR/PReS standards highlight the need to implement a holistic approach to care, which includes vocational and career planning [2]. However, a study evaluating European paediatric rheumatology transitional care practice, found that approximately $36 \%$ used a transitional care checklist and only $50 \%$ of these addressed vocational readiness [4].

As indicated by Walter et al. and others $[1,5]$, interventions are needed to better support young people with

\footnotetext{
* Correspondence: Suzanne.Verstappen@manchester.ac.uk

${ }^{1}$ Centre for Epidemiology Versus Arthritis, The University of Manchester, Manchester, UK

${ }^{2} \mathrm{NIHR}$ Manchester Biomedical Research Centre, Manchester Academic Health Science Centre, Manchester University Hospitals NHS Foundation Trust" Manchester, UK

Full list of author information is available at the end of the article
} 
Table 1 Work experience (N)

\begin{tabular}{|c|c|c|c|c|c|c|}
\hline & $\begin{array}{l}\text { Strongly } \\
\text { agree }\end{array}$ & Agree & $\begin{array}{l}\text { Neither agree } \\
\text { nor disagree }\end{array}$ & Disagree & $\begin{array}{l}\text { Strongly } \\
\text { disagree }\end{array}$ & $\begin{array}{l}\text { Don't } \\
\text { know }\end{array}$ \\
\hline My school offered a placement which matched my career ambitions & 2 & 6 & 2 & 3 & 1 & 0 \\
\hline $\begin{array}{l}\text { My school looked at my strengths and matched these skills with an } \\
\text { employer willing to take on these skills }\end{array}$ & 1 & 5 & 4 & 2 & 2 & 0 \\
\hline $\begin{array}{l}\text { My school encouraged me to try any work despite possible physical } \\
\text { limitations due to my arthritis }\end{array}$ & 1 & 4 & 5 & 2 & 2 & 0 \\
\hline $\begin{array}{l}\text { My school matched my placement/traineeship based on my studies } \\
\text { subjects }\end{array}$ & 3 & 5 & 3 & 1 & 2 & 0 \\
\hline $\begin{array}{l}\text { My school identified placements that stretched/challenged my view } \\
\text { of work }\end{array}$ & 2 & 2 & 6 & 3 & 1 & 0 \\
\hline $\begin{array}{l}\text { My work experience placement/traineeship was easily accessible or } \\
\text { near home }\end{array}$ & 6 & 4 & 2 & 2 & 0 & 0 \\
\hline $\begin{array}{l}\text { My school provided advice about possible limitations about some } \\
\text { placements or traineeships due to my arthritis }\end{array}$ & 1 & 0 & 2 & 7 & 3 & 1 \\
\hline
\end{tabular}

rheumatic conditions to improve transition outcomes. Further research in the UK is needed to explore how such transitional care can improve vocational outcomes. Finding the right first job is likely to influence young people's future employment prospects and career opportunities.

\section{Abbreviations}

EULAR: European League Against Rheumatism; PReS: Pediatric Rheumatology European Society

\section{Acknowledgements}

Not applicable.

\section{Authors' contributions}

LEL analysed and interpreted the patient data regarding young adults with juvenile idiopathic arthritis and their vocational experiences. $A B$ contributed to the conception and design of the work. MB contributed to the conception and design of the work. KWB contributed to the conception and design of the work. KLH interpreted the data and drafted the manuscript. WT interpreted the data and drafted the manuscript. JEM interpreted the data and was a major contributor in writing the manuscript. SMMV contributed to the conception and design of the work and was a major contributor in writing the manuscript. All authors read and approved the final manuscript.

\section{Funding}

This piece of work did not receive funding

\section{Availability of data and materials}

The datasets generated and analysed during the current study are not publicly available, as consent to share publicly was not obtained by participants

\section{Ethics approval and consent to participate}

The study was approved by the University of Manchester Ethics committee (ref. 2017-2112-3266) and all participants gave consent by completing the survey.

\section{Consent for publication}

Not applicable.

\section{Competing interests}

The authors declare that they have no competing interests.

\section{Author details}

${ }^{1}$ Centre for Epidemiology Versus Arthritis, The University of Manchester, Manchester, UK. ${ }^{2} \mathrm{NIHR}$ Manchester Biomedical Research Centre, Manchester
Academic Health Science Centre, Manchester University Hospitals NHS Foundation Trust, Manchester, UK. ${ }^{3}$ National Rheumatoid Arthritis Society, (NRAS), Maidenhead, UK. ${ }^{4}$ Arthritis Research UK/MRC Centre for Musculoskeletal Health and Work, University of Southampton, Southampton, UK. ${ }^{5}$ Centre for Genetics and Genomics Versus Arthritis, The University of Manchester, Manchester, UK.

Received: 7 June 2019 Accepted: 22 July 2019

Published online: 06 August 2019

\section{References}

1. Walter M, Kamphuis S, van Pelt P, de Vroed A, Hazes JMW. Successful implementation of a clinical transition pathway for adolescents with juvenile-onset rheumatic and musculoskeletal diseases. Pediatr Rheumatol Online J. 2018:16(1):50.

2. Foster H, Minden K, Clemente D, Leon L, McDonagh J, Kamphuis S, et al. EULAR/PReS standards and recommendations for the transitional care of young people with juvenile-onset rheumatic diseases. Ann Rheum Dis. 2017;76:639-46.

3. NRAS. Work matters: a UK wide survey of adults with Rheumatoid Arthritis and Juvenile Idiopathic Arthritis on the impact of their disease on work; 2017. p. 1-31

4. Clemente D, Leon L, Foster H, Carmona L, Minden K. Transitional care for rheumatic conditions in Europe: current clinical practice and available resources. Pediatr Rheumatol. 2017;15(1):15-49.

5. Farre A, Ryan S, Mcniven A, McDonagh JE. The impact of arthritis on the educational and early work experiences of young people: a qualitative secondary analysis. Understanding the significance of vocational outcomes for young people with inflammatory arthritis. Int J Adolesc Med Health. 2019. https://doi.org/10.1515/ijamh-2018-0240. [Epub ahead of print]

\section{Publisher's Note}

Springer Nature remains neutral with regard to jurisdictional claims in published maps and institutional affiliations.

Ready to submit your research? Choose BMC and benefit from:

- fast, convenient online submission

- thorough peer review by experienced researchers in your field

- rapid publication on acceptance

- support for research data, including large and complex data types

- gold Open Access which fosters wider collaboration and increased citations

- maximum visibility for your research: over $100 \mathrm{M}$ website views per year

At $\mathrm{BMC}$, research is always in progress.

Learn more biomedcentral.com/submission 